\title{
LIVING LAW DAN 'URF SEBAGAI SUMBER HUKUM POSITIF DI INDONESIA
}

\author{
Nafi' Mubarok \\ Universitas Islam Negeri Sunan Ampel Surabaya, Indonesia \\ E-mail: nafi.mubarok@gmail.com
}

\begin{abstract}
This article deals with the issue of living law and ' $u r f$ as the sources of positive law in Indonesia. The existence of living law and 'urf (habits which are normally and consistently conducted by members of society) are acknowledged in Indonesian legal system. In fact, the theory of living law and 'urf have been adopted as legal reasoning for many laws or bills, such as the law number 23/2014 on local government and the law number $21 / 2008$ on Shariah banking. It can bee seen that many legal decisions by courts judges also have their sources from living laws, such as what deals with criminal sanction, female reciepient of inheritance, the validaty of a merriage. Many legal decisions by court judges also adopt the 'urf, such as the amount of money for 'iddah (waiting time before marriage after divorce), the validity of eloping (kawin lari), shared property in marriage.
\end{abstract}

Keywords: Living law; 'urf; Indonesian legal system.

\section{Pendahuluan}

Indonesia merupakan negara dengan masyarakat yang majemuk, baik secara horizontal maupun vertikal. Secara horizontal Indonesia terdiri atas berbagai penganut agama, kelompok etnis, suku, dan bangsa, sedangkan secara vertikal terdiri atas masyarakat rural dan urban, dengan perbedaan keahlian dan pekerjaan yang terus berkembang secara tajam. Tentunya ini melahirkan berbagai satuan masyarakat dengan ragam karakteristik, baik struktur maupun kebudayaannya. Kemajemukan tersebut juga terdapat dalam tatanan hukum sebagai kelengkapan dalam sistem hukum nasional, yang biasa disebut dengan pluralisme hukum. ${ }^{1}$ Pluralitas hukum inilah yang harus

\footnotetext{
${ }^{1}$ Bani Syarif Maula, "Realitas Hukum Islam dalam Konfigurasi Sosial dan Politik di Indonesia: Perspektif Sosiologi Hukum Tentang Perkembangan Hukum Islam di Indonesia", Hermeneia: Jurnal Kajian Islam Interdisipliner, Vol. 2 No. 2 Juli-Desember 2003), 240.
} 
menjadi fokus utama sebelum menentukan tiga nilai dalam hukum, yaitu kepastian, keadilan, dan kemanfaatan. Dengan kata lain nilai hukum di Indonesia harus bermuara pada hukum yang plural.

Di sisi lain, Von Savigny dengan mazhab sejarahnya menyatakan bahwa hukum merupakan fenomena historis, sehingga keberadaan setiap hukum adalah berbeda yang bergantung pada tempat dan waktu berlakunya hukum, serta hukum harus dipandang sebagai penjelmaan dari jiwa suatu bangsa. Hukum itu tumbuh dan berkembang bersama masyarakat yang sangat tergantung atau bersumber kepada jiwa rakyat tersebut, sehingga yang menjadi isi dari hukum itu ditentukan oleh pergaulan hidup manusia dari masa ke masa, atau aspek historis. Karena itu bisa dikatakan bahwa hukum yang baik adalah hukum yang diciptakan berdasarkan hukum yang hidup di masyarakat, atau yang biasa disebut dengan living law. ${ }^{2}$

Hal ini berangkat dari asumsi bahwa realitas sosial masyarakat telah melahirkan norma hukum yang mengatur tata kehidupan masyarakat sehingga norma hukum yang dilahirkannya pun juga bersifat dinamis. Otoritas yang menentukan keberlakuan hukum bukan hanya semata-mata melalui kekuatan negara, tetapi juga sangat ditentukan realitas hidup masyarakat. Masyarakat juga harus terlibat menentukan keberlakuan hukum tersebut, dikarenakan meskipun regulasi hukum secara eksternal dapat diatur oleh institusi negara, namun dari sisi relasi eksternal dalam kelompok sosial juga bergantung pada kehendak masyarakat. ${ }^{3}$

Di dalam terminologi hukum Islam dikenal 'urf, yang dapat disandingkan dengan living law. Penyandingan 'urf dengan living law sebagai sumber hukum dengan pertimbangan bahwa secara sosiologis dan kultural hukum Islam adalah hukum yang mengalir dan telah berurat akar pada budaya masyarakat Indonesia, karena itulah hukum Islam tergolong sebagai hukum yang hidup di dalam masyarakat (the living (aw). Di samping itu, hukum Islam merupakan entitas agama yang dianut oleh mayoritas penduduk Indonesia, yang dalam dimensi praksisnya hukum Islam telah menjadi bagian tradisi (adat) masyarakat yang terkadang dianggap sakral. ${ }^{4}$

${ }^{2}$ Hayatul Ismi, "Pengakuan dan Perlindungan Hukum Hak Masyarakat Adat atas Tanah Ulayat dalam Upaya Pembaharuan Hukum Nasional", Jurnal Ilmu Hukum, Vol. 3 No. 1 (2012), 1-2.

3 Bernard L. Tanya dkk., Teori Hukum: Strategi Tertib Manusia Lintas Ruang dan Generasi (Surabaya: CV. Kita, 2007), 166.

${ }^{4}$ Maula, Realitas Hukum Islam, 240. 
Tujuan kertas kerja ini adalah mengkaji (1) konsep living law, 'urf, dan titik temu keduanya; (2) pengakuan living law dan 'urf dalam sistem hukum nasional; dan (3) implementasi dari living law dan 'urf, baik dalam produk perundangan-undangan maupun produk putusan hakim.

\section{Konsep Living Law Sebagai Sumber Hukum}

Penggagas dari teori living law ini adalah Eugen Ehrlich $^{5}$, salah satu tokoh sosiologi hukum dari Jerman berkebangsaan Austria. Konsep living law menurutnya bermula dari tiga hal, yaitu: pertama, hukum yang hidup adalah hukum yang mendominasi kehidupan itu sendiri meskipun belum dibahas di dalam proposisi hukum. Sumber pengetahuan tentang hukum adalah dokumen hukum modern dan observasi langsung pada kehidupan, perdagangan, dari adat dan kebiasaan dan semua asosiasi, tidak hanya bermula bahwa hukum telah diakui tetapi juga dari orang-orang yang telah diabaikan dan disahkan, bahkan oleh orang-orang yang telah dipersalahkan". ${ }^{6}$ Kedua, studi tentang norma hukum tidak hanya dalam kaitannya dengan negara, tetapi juga dalam hubungan sosial. ${ }^{7}$ Ketiga, tatanan sosial tidaklah pernah statis. Lembaga yang lama menghilang, selanjutnya lembaga yang baru datang dan menjadi ada, dan orang-orang yang tetap mengubah substansinya secara terus-menerus. ${ }^{8}$

Oleh karena itu, dalam living law dinyatakan bahwa masyarakat merupakan suatu ide umum untuk memahami dan mengkaji hukum. Sebagai ide umum, masyarakat menandakan semua hubungan sosial kemasyarakatan, yang bisa terjadi dalam lingkungan keluarga, lembaga sosial, negara atau bangsa. Hubungan sosial yang bersifat alamiah yang dibangun oleh masyarakat tersebut akan melahirkan hukum. Dari sinilah hukum itu lahir, bermula dari kenyataan-kenyataan sosial yang semula tidak bersifat normatif kemudian menjadi normatif

\footnotetext{
${ }^{5}$ Eugen Ehrlich lahir di Chernivtsi, ibukota Bukovina di Austria (sekarang Ukraina). Dia belajar pada Fakultas Hukum di University of Vienna, dan menjadi dosen pada perguruan tinggi tersebut. selanjutnya dia kembali ke Chernivtsi sebagai profesor dalam hukum Romawi pada tahun 1898. Pada 1906, Eugen Ehrlich menjadi rektor universitas dan meninggal pada tahun 1922. Lihat: Marc Hertogh (et.al), Living Law: Reconsidering Eugen Ehrlich (Oxford: Hart Publishing Ltd, 2009), 22.

6 David Nelken, "Eugen Ehrlich, Living Law, and Plural Legalities", Theoretical Inquiries in Law, Vol. 9.2 (2008), 446.

${ }^{7}$ Hertogh, Living Law, 3.

${ }^{8}$ Ibid., 30.
} 
karena kebiasaan/kekuatan-kekuatan efektif dari masyarakat dan akan terus berevolusi sesuai dengan perkembangannya.'

Teori living law lahir dari proses dialektika antara tesis positivisme hukum dan antitesis aliran sejarah. ${ }^{10}$ Positivisme hukum mengajarkan bahwa hukum positif adalah hukum yang berlaku, yang mewujud dalam norma-norma yudisial yang telah dibangun oleh otoritas negara. Hukum negara ditaati secara absolut yang disimpulkan ke dalam suatu pernyataan the law is the law. ${ }^{11}$ Hukum bukan merupakan produk dari fakta sosial, melainkan produk dari lembaga yang berwenang yang selalu memiliki bentuk formal. ${ }^{12}$ Oleh karena itu paradigma positivisme hukum bersifat abstrak dan formal legalistis.

Hal ini berbeda dengan paradigma living law yang bersifat yuridis sosiologis atau yuridis empiris, sehingga analisis hukumnya difokuskan pada lingkungan sosial yang membentuknya, bukan suatu analisis hukum yang bersifat abstrak dan ideologis. Asumsinya bahwa persoalan-persoalan tentang hukum, pada saat ini, tidak lagi merupakan persoalan tentang legal-formal dan penafsiran pasal-pasal peraturan perundang-undangan, melainkan bergerak menuju pada penggunaan hukum sebagai sarana untuk turut membentuk tata kehidupan yang baru atau sesuai dengan kondisi saat itu. Dengan kata lain, hukum positif baru akan berlaku secara efektif apabila berisikan atau selaras dengan hukum yang hidup dalam masyarakat. ${ }^{13}$

Dikarenakan ide dasar dari living law adalah masyarakat, maka semua hukum positif harus berakar dalam suatu hukum fundamental masyarakat, atau realitas kehidupan sosial. Oleh karenanya, norma hukum yang dilahirkannya pun bersifat dinamis sebagaimana sistem tata kehidupan masyarakat yang dinamis. Di samping itu, hukum lahir dan berkembang bukan dari realitas a-historis, melainkan dari realitas historis masyarakat itu sendiri, dikarenakan hukum merupakan bagian eksistensial dari sejarah hidup masyarakat. ${ }^{14}$

\footnotetext{
${ }^{9}$ Kuswardani, "Pengembangan Metodologi Berbasis Sociology Jurisprudence", Prosiding Seminar Nasional Pengembangan Epistemologi Imu Hukum, Surakarta, UMS (April-2015), 114-115.

${ }^{10}$ R. Otje Salman, Beberapa Aspek Sosiologi Hukum (Bandung: Alumni, 1993), 3-4.

11 Ade Maman Suherman, Pengantar Perbandingan Sistem Hukum, Civil Law, Common Law, Hukum Islam (Jakarta: Raja Grafindo Persada, 2006), 37-38.

12 Kuswardani, Pengembangan Metodologi, 115.

${ }^{13}$ Salman, Beberapa Aspek Sosiologi Hukum, 1-3.

14 Sirajuddin M, "Eksistensi Urf sebagai Sumber Pelembagaan Hukum Nasional", Madania, Vol. 19, No. 1 (Juni 2015), 20.
} 
Di samping itu, dikarenakan lahir dari realitas kehidupan sosial, maka hukum memiliki konotasi "hukum sosial". Hukum lahir dalam dunia pengalaman manusia yang bergumul dengan kehidupan seharihari yang terbentuk lewat kebiasaan dan lambat laun mengikat dan menjadi tatanan yang efektif, yang selanjutnya kehidupan berjalan dalam tatanan tersebut. Kekuasan mengikat hukum yang hidup tidak ditentukan oleh kewibawaan negara. ${ }^{15}$ Dengan demikian, otoritas yang menentukan keberlakuan hukum tersebut bukan semata melalui kekuatan negara, tetapi juga sagat ditentukan realitas hidup masyarakat. Masyarakat juga punya andil dalam menentukan keberlakuan hukum tersebut. Meskipun regulasi hukum secara eksternal dapat diatur oleh institusi negara, tetapi dari sisi relasi-relasi eksternal dalam kelompok sosial bergantung pada kehendak masyarakat. ${ }^{16}$

Karena itu, akhirnya Ehrlich menyimpulkan pendapatnya bahwa pengaruh hukum negara tumbuh sesuai dengan intensifikasi solidaritas, dengan mengatakan bahwa: "fakta bahwa hukum negara secara nyata mendapatkan tempat hanyalah ekspresi setelah adanya solidaritas intensif dari masyarakat". ${ }^{17}$

Dari pemaparan tersebut, dapat disimpulkan bahwa pokok-pokok pemikiran living law dari Eugen Ehrlich adalah sebagai berikut: ${ }^{18}$

1. Norma hukum merupakan produk masyarakat yang berupa kebiasaan yang berkembang dalam masyarakat.

2. Kekuatan mengikat dari hukum tidak terletak pada peraturan perundangan atau keputusan pengadilan melainkan terletak pada masyarakat itu sendiri, sehingga sumber hukum yang riil bukan undang-undang atau jurisprudensi, melainkan adalah aktivitas masyarakat itu sendiri.

3. Hukum positif adalah proposisi yang sudah dilegislasi oleh negara yang harus bersumber pada hukum yang hidup yaitu kebiasaan yang berkembang dan berfungsi sebagai aturan perilaku.

Sedangkan cara untuk melakukan penelitian hukum yang hidup dalam masyarakat (living law) dapat dilakukan dengan tiga tipe, yaitu:

1. Ideological method, yaitu dengan meneliti norma-norma abstrak yang direkam dari ingatan-ingatan para kepala adat, tokoh masyarakat,

${ }^{15}$ Kuswardani, Pengembangan Metodologi, 115.

16 Sirajuddin M, "Eksistensi 'Urf', 20.

17 Mikhail Antonov, "Eugen Ehrlich: State Law and Law Enforcement in Societal Systems", Law WP-BRP, Vol. 33 (2014), 4.

${ }^{18}$ Kuswardani, Pengembangan Metodologi, 114. 
atau pemegang otoritas yang diberi wewenang membuat keputusan-keputusan hukum.

2. Descriptive method, yaitu dengan melakukan pengamatan terhadap setiap tindakan nyata (perilaku) aktual anggota masyarakat dalam kehidupan sehari-hari ketika berinteraksi dalam komunitasnya.

3. Trouble-cases method, yaitu dengan mengkaji kasus-kasus sengketa yang pernah atau sedang terjadi dalam masyarakat. ${ }^{19}$

\section{Konsep 'Urf sebagai Sumber Hukum Islam}

Kata 'urf berasal dari 'a-r-f yang secara etimologi berarti "sesuatu yang dipandang baik, yang dapat diterima akal sehat. ${ }^{20}$ Menurut 'Abd al-Wahhâb al-Khallâf: "Urf adalah sesuatu yang dikenal dan biasa dilakukan oleh mayoritas orang, baik berbentuk kata-kata, perbuatan atau sesuatu yang ditinggalkan". 21 Sedangkan menurut al-Zuhaylî, " Urf adalah sesuatu yang dikenal dan biasa dilakukan oleh mayoritas orang serta populer di antara mereka, atau perkataan yang bermakna umum namun mereka kenal dengan makna khusus". 22

Berkenaan dengan 'urf dijadikan sebagai dalil sumber hukum, terdapat argumentasi yang diajukan, yaitu:

1. Argumentasi 'urf dalam al-Qur'ân adalah firman Allah QS. al-A'râf [7]: 199, yang artinya: "Jadilah engkau pemaaf dan suruhlah orang yang mengerjakan yang ma'rûf, serta berpalinglah dari orang-orang yang bodoh". Terdapat tiga penafsiran kata 'urf dalam ayat tersebut, yaitu: (1) apa yang baik dan terpuji, (2) apa yang dikenal dan diterima sebagai praktik umum yang baik, dan (3) apa yang dikenal menjadi penting dan diperlukan. ${ }^{23}$

2. Argumentasi 'urf dari hadîth adalah perkataan 'Abd Allâh b. Mas'ûd, bahwa "Sesuatu yang dinilai baik oleh kaum muslimin adalah baik di sisi Allah, dan sesuatu yang dinilai buruk maka ia buruk disisi Allah”. Memang ini bukan hadîth, akan tetapi

19 I Nyoman Nurjaya, "Memahami Kedudukan dan Kapasitas Hukum Adat dalam Politik Pembangunan Hukum Nasional", Perspektif, Vol. 16, No. 4 (September2011), 238.

20 Dedeng Rosidin, Diktat Ushul Fiqih (Bandung: FPBS-Universitas Pendidikan Bandung, 2010), 90.

21 'Abd al-Wahhâb Khallâf, Tlm Usû́l al-Fiqh (Mesir: Maktabah al-Dakwah-Syababul Azhar, 2009), 89.

22 Wahbah al-Zuhaylî, al-Wajî̀ fî Ușûl al-Fiqh (Damaskus: Dâr al-Fikr, 1999), 97.

23 Ayman Shabana, Custom in Islamic Law and Legal Theory: The Development of the Concepts of 'Urf and 'Adah in the Islamic Legal Tradition (New York: Palgrave Macmillan, 2010), 51-52. 
perkataan sahabat Nabi Muhammad. Meskipun begitu oleh para ulama dikategorikan sebagai hadîth mawqûf, sehingga meskipun ucapan Ibn Mas'ûd, akan tetapi kemungkinan besar adalah perkataan $\mathrm{Nabi}^{24}$

3. Argumentasi logis (naqli) dari 'urf adalah bahwa sharî'ah Islam ditakdirkan untuk terus dan selamanya, sehingga berakibat bahwa aturan dan prinsip-prinsipnya harus terus berlaku, dapat digunakan dan praktis untuk setiap masa. Setiap orang bisa menggunakannya dengan berdasarkan realitas yang telah ada di masa lalu dan akan terus ada di masa depan. Banyak dari permasalahan ekonomi, sosial dan perkawinan dalam hukum Islam yang didasarkan pada adat dan kebiasaan. ${ }^{25}$

Selanjutnya, 'urf dari aspek kebolehannya dijadikan sebagai sumber hukum, dibedakan menjadi al-urf al-sahîh dan al-urf al-fâsid. Al-'urf alsaḩîh (kebiasaan yang dianggap sah), yaitu kebiasaan yang berlaku ditengah-tengah masyarakat yang tidak bertentangan dengan alQur'ân dan hadîth, tidak menghilangkan kemaslahatan mereka, dan tidak pula membawa kerusakan kepada mereka, sehingga tidak menghalalkan yang haram dan juga tidak membatalkan yang wajib. ${ }^{26}$ Ini semisal kebiasaan istri tidak pindah ke rumah suaminya sebelum menerima sebagian maharnya, atau dalam pertunangan pihak laki-laki memberikan hadiah kepada pihak perempun dan hadiah ini tidak dianggap sebagai mas kawin, ${ }^{27}$ atau kebiasaan yang berlaku dalam dunia perdagangan tentang indent. ${ }^{28}$

Sedang al-urf al-fâsid adalah praktik-praktik yang masyhur di antara orang-orang, akan tetapi bertentangan dengan hukum ilahi, atau melegitimasi sesuatu yang dilarang, atau menolak suatu tindakan wajib, atau membawa kamudaratan, atau berakibat pada tujuan yang tidak bermanfaat. Dengan demikian, al-urf al-fâsid ini merupakan kebiasaan yang membatalkan nass. hukum ilahi atau bertentangan dengan keabsahan dan melawan hukum, di mana penggunaannya

\footnotetext{
24 Ibid., 52-53.

${ }^{25} \mathrm{Hafiz}$ Abdul Ghani, "UUrf -o-Ādah (Custom and Usage) as a Source of Islamic Law", American International Journal of Contemporary Research, Vol. 1 No. 2 (September 2011), 184.

${ }^{26}$ Khallâf, Tlm Ușûl al-Fiqh, 90.

27 al-Zuhaylî, al-Wajî̃ fì Usûul al-Fiqh, 98.

${ }^{28}$ Rosidin, Diktat Ushul Fiqih, 90.
} 
tidak dapat dianggap sebagai hukum. ${ }^{29}$ Contohnya kebiasaan yang berlaku di kalangan pedagang dalam menghalalkan riba, seperti peminjaman uang antar-pedangang, memberikan jamuan minuman keras, ${ }^{30}$ atau kebiasaan dalam mencari dana dengan cara mengadakan berbagai macam kupon berhadiah. ${ }^{31}$

Agar "urf bisa divalidasi sebagai sumber hukum, atau disebut sebagai al-urf al-sabîth, maka diperlukan tiga syarat, antara lain: 1). 'Urf tersebut harus dominan. Artinya, urf tersebut harus dominan dan dijalankan secara terus-menerus mayoritas masyarakat. $\left.{ }^{32} 2\right)$. 'Urf harus sudah terlebih dahulu berlaku saat peraturan dibuat atau perbuatan terjadi. Artinya, ketika perbuatan berlangsung, 'urf harus sudah biasa digunakan terlebih dahulu. ${ }^{33} 3$ ). 'Urf harus sesuai dengan al-Qur'ân dan hadîth. Dengan demikian, teks al-Qur'ân dan hadîth harus lebih dimenangkan daripada kebiasaan atau 'urf, karena ada kemungkinan bahwa "urf dalam penggunaannya berdasar pada suatu kedustaan. ${ }^{34}$

Menurut mazhab Mâlikî, terdapat empat tingkat penggunaan 'urf, antara lain:

1. Tingkat pertama'urf yang sudah ada selama masa Nabi Muhammad, seperti penggunaan timbangan untuk mengukur dan menimbang, di mana penggunaan 'urf ini sebagai sumber hukum sudah disepakati.

2. Tingkat kedua 'urf penduduk Madinah sampai kewafatan khalifah 'Uthmân b. 'Affân, yang menurut Imam Mâlik 'urf ini bisa dijadikan sebagai sumber hukum.

3. Tingkat ketiga terdapat dua 'urf dan penduduk Madinah memilih salah satunya. Menurut Imam Mâlik dan Imam al-Shâfi'î, 'urf tersebut merupakan sumber hukum, namun tidak demikian dengan Imam Abû Ḥanîfah dan Imam Aḥmad.

4. Tingkat keempat, 'urf penduduk Madinah setelah kewafatan khalifah 'Uthmân b. 'Affân. Menurut Imam Abû Ḥanîfah, Imam

\footnotetext{
${ }^{29}$ Hafiz Abdul Ghani, "Conditions of a Valid Custom in Islamic and Common Laws", International Journal of Business and Social Science, Vol. 3 No. 4 (Special IssueFebruary 2012), 306.

30 al-Zuhaylî, al-W ajî̀ fî̀ Ușûl al-Figh, 98.

${ }^{31}$ Rosidin, Diktat Ushul Fiqih, 90.

${ }^{32}$ Ghani, Conditions of a V alid Custom, 312-313.

${ }^{33}$ Ibid., 314.

${ }^{34}$ Ibid., 315.
} 
al-Shâfi'î dan Imam Aḥmad bahwa 'urf tersebut bukan merupakan sumber hukum, namun tidak demikian dengan Imam Mâlik. ${ }^{35}$

\section{Titik Temu antara Living Law dan 'Urf}

Dengan deskripsi teori living law dan 'urf di atas dapat ditarik benang merah bahwa antara living law dan 'urf adalah sama. Bisa dikatakan living law adalah 'urf, dan sebaliknya. Hal ini dikarenakan living law merupakan hukum yang mendominasi kehidupan itu sendiri meskipun belum dibahas di dalam proposisi hukum. Sedangkan 'urf merupakan sesuatu yang biasa dilakukan dan telah umum dalam sekelompok orang (jumbûr) berupa perkataan dan perbuatan, dan secara konsisten diulang sampai mempengaruhi mereka dan oleh karena itu mereka menerimanya. Dengan demikian, hukum adalah sesuatu yang eksis dan sudah menjadi tradisi meskipun itu bukan merupakan hukum, yang dalam hukum positif disebut dengan undang-undang dan dalam hukum Islam disebut al-Qur'ân dan hadith.

Berkenaan dengan 'urf, Ayman Shabana menyatakan bahwa pembicaraan hubungan antara 'urf dan hukum Islam merupakan objek yang menarik dalam perspektif para akademisi modern yang ingin mendalami tradisi hukum Islam. Bahkan, objek ini telah berhubungan erat dengan dua perdebatan utama yang sebagian besar telah membentuk bidang studi Islam modern di Barat, yaitu perdebatan tentang asal-usul dan sifat hukum Islam. Selain itu ihwal "kebiasaan" telah muncul di banyak disiplin ilmu, seperti sejarah, hukum, sosiologi, dan antropologi, meskipun masing-masing bidang memiliki metodologi dan strategi yang khas. ${ }^{36}$

\section{Eksistensi Living Law dan ' $U r f$ dalam Sistem Hukum Nasional}

Sistem hukum yang dipergunakan di Indonesia adalah sistem hukum civil law, yaitu sistem hukum kodifikasi atau tertulis. ${ }^{37}$ Hukum hanya ada dalam peraturan perundang-undangan formal yang proses pembentukanya melalui lembaga legislatif, sedangkan hukum yang lahir diluar proses lembaga legislatif harus dianggap sebagai hukum yang tidak mempunyai otoritas sebagai hukum terapan yang

\footnotetext{
35 Ghani, Urf-o-Ädah (Custom and Usage), 183.

36 Shabana, Custom in Islamic Law, 17.

37 Dhoni Yusra, "Politik Hukum Hakim dibalik Penemuan Hukum (Rechtsvinding) dan Penciptaan Hukum (Rechtsschepping) pada Era Reformasi dan Transformasi", Lex Jurnalica, Vol. 10 No. 2 (Agustus 2013), 64.
} 
mengikat. ${ }^{38}$ Dengan demikian, dalam sistem hukum civil law, hukum sengaja dikontruksi dalam bentuk rumusan tertulis yang disusun secara sistematis dalam kitab hukum perundang-undangan, dan hakim terikat secara rigid untuk menerapkannya secara apa adanya. ${ }^{39}$ Karenanya, sistem hukum ini telah menempatkan hakim hanya sebagai corong undang-undang atau juru bicara undang-undang. Dalam konteks menjalankan fungsi kekuasaan kehakiman, seorang hakim tidak berkompeten menafsirkan pasal-pasal dalam undangundang, adil atau tidak adilnya undang-undang mesti diterapkan oleh hakim, meskipun bertentangan dengan keyakinan dan hati nurani. ${ }^{40}$

Salah satu titik lemah dari sistem hukum civil law yang mendasarkan pada hukum yang tertulis dan kodifikasi adalah pengodifikasian hukum tidak akan mampu menampung semua aspirasi masyarakat. Hal ini dikarenakan substansi suatu undangundang pada dasarnya tidak lengkap atau tidak jelas, ${ }^{41}$ sehingga betapapun cepatnya pembuat undang-undang bekerja tidak akan mampu mengakomodir persoalan yang timbul dalam masyarakat yang membutuhkan pengaturan yang terus bertambah dan berkembang dengan cepat. ${ }^{42}$

Bagir Manan-sebagaimana dikutip Hwian Christiantomenjelaskan tentang batasan-batasan (limitation) dari sebuah peraturan perundang-undangan, antara lain:

1. Tidak pernah ada satu peristiwa hukum yang tepat dalam peraturan perundang-undangan.

2. Suatu perbuatan tidak tercakup dalam kata atau kata-kata yang disebut dalam peraturan perundang-undangan.

3. Makna bahasa sangat terbatas jika dibandingkan dengan gejala atau peristiwa yang terjadi di masyarakat, baik peristiwa hukum, politik, ekonomi, maupun sosial.

4. Bahasa dapat diartikan berbeda pada setiap lingkungan masyarakat karena faktor sosiologis, sehingga menjadi tidak jelas, bermakna ganda, tidak konsisten bahkan ada pertentangan atau unreasonable.

5. Tuntutan keadilan.

38 Lili Rasjidi dan Ira Tania Rasjidi, Dasar-dasar Filsafat Hukum dan Teori Hukum (Bandung: Citra Aditya Bakti, 2004), 56.

${ }^{39}$ Ibid., 63.

40 Cut Asmaul Husna TR, "Penemuan dan Pembentukan Hukum "The Living Law" Melalui Putusan Hakim”, Mizan, Vol. 2 No. 3 (Februari 2012), 72-73.

${ }^{41}$ Sudikno, Mengenal Hukum (Yogyakarta: Liberty, 1999), 147.

${ }^{42}$ Yusra, Politik Hukum Hakim, 65. 
6. Adanya pengaruh perkembangan masyarakat dan transformasi atau resepsi konsep hukum asing yang dipergunakan dalam praktik hukum.

7. Pengaruh berbagai teori baru di bidang hukum, semisal sociological jurisprudence dan feminist legal theory. ${ }^{43}$

Oleh karena itu sering terjadi dalam masyarakat persoalan yang belum ada peraturannya, yang biasa dikenal dengan kekosongan hukum. Untuk mengantisipasi hal tersebut, maka perlu dilakukan pengisian kekosongan hukum yang dalam sistem hukum formal dilakukan oleh hakim. Hal itu terjadi ketika diajukan kepada hakim suatu perkara yang tidak diatur dalam peraturan perundang-undangan yang berlaku, atau peraturan perundang-undangan yang ada dan berlaku tidak mungkin diterapkan walau ditafsirkan sekalipun. ${ }^{44}$ Ini dikarenakan hakim tidak boleh menolak perkara dengan alasan hukum tidak ada, tidak lengkap, atau hukum samar-samar. ${ }^{45}$

Pengisian kekosongan hukum oleh hakim ini diatur dalam Undang-undang No. 48 Tahun 2009 tentang Kekuasaan Kehakiman pada Pasal 10 ayat (1), yaitu: "Pengadilan dilarang menolak untuk memeriksa, mengadili, dan memutus suatu perkara yang diajukan dengan dalih bahwa hukum tidak ada atau kurang jelas, melainkan wajib untuk memeriksa dan mengadilinya". Dengan demikian, tidak ada lagi kondisi kekosongan hukum, bahkan hal itu dilarang dijadikan argumen untuk tidak mengadili atau memberikan hukum.

Kegiatan hakim untuk mengisi kekosongan hukum dalam sistem hukum adalah dengan melakukan kreasi hukum. Bentuknya bisa berupa penemuan hukum (rechtsvinding) atau penciptaan hukum (rechtsschepping). ${ }^{46}$

Menurut Achmad Ali-dalam kaitannya dengan penemuan hukum-hakim diberikan kebebasan yang seluas-luasnya untuk melakukan penemuan hukum, sehingga tidak hanya sekadar menerapkan undang-undang akan tetapi juga mencakup memperluas dan membentuk peraturan dalam putusan hakim. Bahkan, demi

\footnotetext{
${ }^{43}$ Hwian Christianto, "Penafsiran Hukum Progresif dalam Perkara Pidana", Mimbar Hukum, Vol. 23, No. 3 (Oktober 2011), 486.

${ }^{44}$ Yusra, Politik Hukum Hakim, 65.

45 Nafi' Mubarok, "Penemuan Hukum sebagai Pertimbangan Sosiologis Hakim Agama dalam Menerapkan Hukum”, al-Qânûn, Vol. 17, No. 2 (Desember 2014), 372.

${ }^{46}$ Yusra, Politik Hukum Hakim, 65.
} 
mencapai keadilan yang setinggi-tingginya, hakim diperbolehkan menyimpang dari undang-undang demi kemaslahatan masyarakat. ${ }^{47}$

Landasan yuridis dari kreasi hukum tersebut adalah Pasal 5 ayat (1) Undang-Undang Nomor 48 Tahun 2009 tentang Kekuasaan Kehakiman, yaitu: "Hakim dan hakim konstitusi wajib menggali, mengikuti, dan memahami nilai-nilai hukum dan rasa keadilan yang hidup dalam masyarakat". ${ }^{48}$ Tujuannya adalah sebagaimana dalam penjelasan dari pasal tersebut: "Ketentuan ini dimaksudkan agar putusan hakim dan hakim konstitusi sesuai dengan hukum dan rasa keadilan masyarakat". ${ }^{49}$

Dengan Pasal tersebut, hakim diposisikan sebagai perumus dan penggali dari nilai-nilai hukum yang hidup di masyarakat. Untuk itu, hakim harus terjun ke tengah-tengah masyarakat untuk mengenal, merasakan, dan menyelami perasaan hukum dan rasa keadilan yang hidup dalam masyarakat. Dengan begitu hakim dapat memberi putusan yang sesuai dengan hukum dan keadilan masyarakat. ${ }^{50}$

Di sisi lain, dalam ilmu hukum dikenal sumber hukum formal, yang terdiri dari: undang-undang, adat dan kebiasaan, traktat, keputusan hakim atau yurisprudensi, dan pendapat ahli hukum terkenal atau doktrin. ${ }^{51}$

Adapun pengertian dari kebiasaan-menurut JB. Daliyo—adalah perbuatan manusia yang dilakukan berulang-ulang mengenai hal tingkah laku kebiasaan yang diterima oleh suatu masyarakat yang selalu dilakukan oleh orang lain sedemikian rupa. ${ }^{52}$ Sedangkan kebiasaan menurut Kansil, adalah kebiasaan merupakan perbuatan manusia yang tetap dilakukan dalam hal yang sama. ${ }^{53}$

Menurut Kansil, apabila kebiasaan tertentu diterima oleh masyarakat dan kebiasaan itu dilakukan berulang-ulang, sehingga tindakan yang berlawanan dengan kebiasaan itu dirasakan sebagai pelanggaran perasaan hukum. Dengan demikian muncul kebiasaan

47 Achmad Ali, Menguak Tabir Hukum (Jakarta: Gunung Agung, 2002), 138; Rodrigo Fernandes Elias, "Penemuan Hukum dalam Proses Peradilan Pidana di Indonesia", Jurnal LPPM Bidang EkoSosBudKum, Vol. 1 No. 1 (2014), 4.

${ }^{48}$ Husna TR, Penemuan dan Pembentukan Hukum, 62.

49 Mubarok, "Penemuan Hukum", 373.

${ }^{50}$ Husna TR, Penemuan dan Pembentukan Hukum, 62.

${ }^{51}$ Marhaenis Abdul Hay, Dasar-dasar Imu Hukum (Jakarta: Pradnya Paramita, 1986), 146.

52 Sudikno, Mengenal Hukum, 84.

53 C.S.T. Kansil, Pengantar Ilmu Hukum dan Tata Hukum Indonesia (Jakarta: Balai Pustaka, 1989), 48. 
hukum yang dalam pergaulan hidup masyarakat dipandang sebagai hukum..$^{54}$

Dua hal tersebut, (1) kewajiban hakim menggali, mengikuti, dan memahami nilai-nilai hukum dan rasa keadilan yang hidup dalam masyarakat dan (2) pengakuan kebiasaan sebagai sumber hukum formal, merupakan landasan logis-yuridis dari wujud pengakuan dari living law dan 'urf dalam sistem hukum di Indonesia sebagai salah satu sumber hukum. Sedangkan landasan yuridis konstitutifnya adalah Pasal 32 ayat (1) dari Undang-Undang Dasar Negara Republik Indoneisa Tahun 1945, yaitu: "Negara memajukan kebudayaan nasional Indonesia di tengah peradaban dunia dengan menjamin kebebasan masyarakat dalam memelihara dan mengembangkan nilainilai budayanya".

\section{Implementasi Living Law dan ' $U$ tf pada Perundang-undangan}

Sebagaimana dipaparkan sebelumnya, bahwa living law dan 'urf diakui eksistensinya dalam sistem hukum nasional. Berikut ini diajukan beberapa peraturan perundang-undangan yang merupakan implementasi dari living law dan 'urf, baik yang berbentuk undangundang atau peraturan daerah, antara lain:

Pertama, undang-undang Nomor 23 Tahun 2014 tentang Pemerintahan Daerah, yang dalam penjelasannya pada alinea lima disebutkan: "Daerah sebagai satu kesatuan masyarakat hukum yang mempunyai otonomi berwenang mengatur dan mengurus daerahnya sesuai aspirasi dan kepentingan masyarakatnya sepanjang tidak bertentangan dengan tatanan hukum nasional dan kepentingan umum. Dalam rangka memberikan ruang yang lebih luas kepada daerah untuk mengatur dan mengurus kehidupan warganya, maka pemerintah pusat dalam membentuk kebijakan harus memperhatikan kearifan lokal dan sebaliknya daerah ketika membentuk kebijakan daerah baik dalam bentuk perda maupun kebijakan lainnya hendaknya juga memperhatikan kepentingan nasional. Dengan demikian akan tercipta keseimbangan antara kepentingan nasional yang sinergis dan tetap memperhatikan kondisi, kekhasan, dan kearifan lokal dalam penyelenggaraan pemerintahan secara keseluruhan". Bukti adanya pengakuan terhadap living law atau "urf adalah: (1) "mengatur dan mengurus daerahnya sesuai aspirasi dan kepentingan masyarakatnya", (2) "harus memperhatikan kearifan lokal", dan (3) "memperhatikan kondisi, kekhasan, dan kearifan lokal".

${ }^{54}$ Ibid., 49. 
Kedua, undang-undang Nomor 21 Tahun 2008 tentang Perbankan Syariah, yang dalam konsiderannya dinyatakan: "pelembagaan norma hukum Islam dalam hukum nasional, terutama dalam bidang perekonomian menjadi perhatian semua pihak dan menjadi kehendak warga masyarakat Muslim Indonesia". Sedangkan dalam penjelasan undang-undang tersebut disebutkan: "Agar tercapai tujuan pembangunan nasional dan dapat berperan aktif dalam persaingan global yang sehat, diperlukan partisipasi dan kontribusi semua elemen masyarakat untuk menggali berbagai potensi yang ada di masyarakat guna mendukung proses akselerasi ekonomi dalam upaya merealisir tujuan pembangunan nasional. Salah satu bentuk penggalian potensi dan wujud kontribusi masyarakat dalam perekonomian nasional tersebut adalah pengembangan sistem ekonomi berdasarkan nilai Islam (sharî́ah) dengan mengangkat prinsip-prinsipnya ke dalam sistem hukum nasional". Bukti adanya pengakuan terhadap living law atau "urf adalah: (1) "kehendak warga masyarakat Muslim Indonesia", dan (2) penggalian potensi dan wujud kontribusi masyarakat dalam perekonomian nasional".

Ketiga, Undang-Undang Nomor 23 Tahun 2011 tentang Pengelolaan Zakat, yang dalam konsideran disebutkan: "bahwa asas pelembagaan norma hukum Islam yang hidup di masyarakat dalam hukum nasional adalah prinsip kemerdekaan tiap-tiap penduduk untuk memeluk agamanya masing-masing dan untuk beribadat menurut agama dan kepercayaannya. Selain itu, zakat merupakan norma hukum Islam yang hidup dan wajib dilaksanakan oleh Muslim". Sedangkan dalam penjelasan undang-undang tersebut dinyatakan: "Zakat wajib didistribusikan kepada mustahik sesuai dengan sharî́ah Islam. Pendistribusian dilakukan berdasarkan skala prioritas dengan memperhatikan prinsip pemerataan, keadilan, dan kewilayahan". Bukti adanya pengakuan terhadap living law atau "urf adalah: (1) "prinsip kemerdekaan tiap-tiap penduduk untuk memeluk agamanya masing-masing dan untuk beribadat menurut agamanya dan kepercayaannya", (2) "norma hukum Islam yang hidup dan wajib dilaksanakan oleh Muslim", dan (3) "memperhatikan prinsip pemerataan, keadilan, dan kewilayahan".

Keempat, Undang-undang Nomor 44 Tahun 1999 tentang Penyelenggaraan Keistimewaan Propinsi Daerah Istimewa Aceh, yang dalam konsiderannya dinyatakan: "a. sejarah panjang perjuangan rakyat Aceh membuktikan adanya ketahanan dan daya juang yang 
tinggi, yang bersumber dari kehidupan yang religius, adat yang kukuh, dan budaya Islam yang kuat dalam menghadapi kaum penjajah; b. kehidupan religius rakyat Aceh yang telah membentuk sikap pantang menyerah dan semangat nasionalisme dalam menentang penjajah dan mempertahankan kemerdekaan merupakan kontribusi yang besar dalam menegakkan Negara Kesatuan Republik Indonesia meskipun rakyat Aceh kurang mendapat peluang untuk menata diri; c. kehidupan masyarakat Aceh yang religius, menjunjung tinggi adat, dan telah menempatkan ulama pada peran yang terhormat dalam kehidupan bermasyarakat, berbangsa, dan bernegara perlu dilestarikan dan dikembangkan bersamaan dengan pengembangan pendidikan; dan d. sehubungan dengan hal-hal tersebut serta untuk penyelenggaraan pemerintahan daerah yang memerlukan adanya jaminan kepastian hukum dalam melaksanakan segala urusan, perlu dibentuk Undang-undang tentang Penyelenggaraan Keistimewaan Propinsi Daerah Istimewa Aceh. Bukti adanya pengakuan terhadap living law atau 'urf adalah: (1) "bersumber dari kehidupan yang religius, adat yang kukuh, dan budaya Islam yang kuat", (2) "telah membentuk sikap pantang menyerah dan semangat nasionalisme", (3) "perlu dilestarikan dan dikembangkan bersamaan dengan pengembangan pendidikan", dan (4) "memerlukan adanya jaminan kepastian hukum dalam melaksanakan segala urusan".

Kelima, Peraturan Daerah Provinsi Gorontalo Nomor 10 Tahun 2003 tentang Pencegahan Maksiat, yang di dalam konsiderannya disebutkan: "a. Provinsi Gorontalo merupakan Daerah Adat ke-9 dari 19 Daerah Hukum Adat di Indonesia, yang memiliki budaya dengan landasan filosofi Adat bersendikan Syara-Syara bersendikan Kitabullah yang perlu dipertahankan"; dan b. berbagai bentuk maksiat sudah sangat meresahkan, mengganggu keamanan, ketertiban serta sendi-sendi kehidupan masyarakat karena perbuatan tersebut bertentangan dengan norma-norma agama, kesusilaan dan norma adat, sehingga perlu melindungi kestabilan masyarakat". Pengakuan terhadap living law atau "urf terlihat dengan: (1) mengakui tata nilai dan norma hukum yang berwawasan keislaman, dan (2) mengembangkan tradisi budaya masyarakat agar menjadi salah satu norma hukum yang harus ditaati bersama.

Keenam, Peraturan Daerah Kota Tangerang Nomor 8 Tahun 2005 tentang Pelarangan Pelacuran, yang dalam konsiderannya dinyatakan: "a. Pelacuran merupakan suatu perbuatan yang bertentangan dengan 
norma agama dan kesusilaan yang berdampak negatif terhadap sendisendi kehidupan masyarakat". Pengakuan terhadap living law atau "urf terlihat dengan berlandaskan dan bersumber dari tata nilai dan budaya masyarakatnya. Di samping, juga berusaha mencegah terjadinya pelacuran yang hendak mengancam tata nilai dan budaya masyarakat di Kota Tangerang.

Dari beberapa contoh beberapa peraturan perundang-undangan di atas, maka dapat disajikan tabel sebagai berikut:

\begin{tabular}{|c|c|c|}
\hline No & $\begin{array}{l}\text { Perundang- } \\
\text { undangan }\end{array}$ & Pengakuan Living Law dan' 'Urf \\
\hline 1 & $\begin{array}{l}\text { Undang-undang } \\
\text { Nomor } 23 \text { Tahun } 2014 \\
\text { tentang Pemerintahan } \\
\text { Daerah }\end{array}$ & $\begin{array}{l}\text { Mengatur dan mengurus daerahnya } \\
\text { sesuai aspirasi dan kepentingan } \\
\text { masyarakatnya. } \\
\text { Harus memperhatikan kearifan lokal. } \\
\text { Memperhatikan kondisi, kekhasan, dan } \\
\text { kearifan lokal. }\end{array}$ \\
\hline 2 & $\begin{array}{l}\text { Undang-undang } \\
\text { Nomor } 21 \text { Tahun } 2008 \\
\text { tentang } \quad \text { Perbankan } \\
\text { Syariah }\end{array}$ & $\begin{array}{l}\text { Kehendak warga masyarakat Muslim } \\
\text { Indonesia. } \\
\text { Penggalian potensi dan wujud kontribusi } \\
\text { masyarakat dalam perekonomian } \\
\text { nasional }\end{array}$ \\
\hline 3 & $\begin{array}{l}\text { Undang-Undang } \\
\text { Nomor } 23 \text { Tahun } 2011 \\
\text { tentang } \quad \text { Pengelolaan } \\
\text { Zakat }\end{array}$ & $\begin{array}{l}\text { Prinsip kemerdekaan tiap-tiap penduduk } \\
\text { untuk memeluk agamanya masing- } \\
\text { masing dan untuk beribadat menurut } \\
\text { agamanya dan kepercayaannya. } \\
\text { Norma hukum Islam yang hidup dan } \\
\text { wajib dilaksanakan oleh Muslim. } \\
\text { Memperhatikan prinsip pemerataan, } \\
\text { keadilan, dan kewilayahan. }\end{array}$ \\
\hline 4 & $\begin{array}{l}\text { Undang-undang } \\
\text { Nomor } 44 \text { Tahun } 1999 \\
\text { tentang } \\
\text { Penyelenggaraan } \\
\text { Keistimewaan Propinsi } \\
\text { Daerah Istimewa Aceh. }\end{array}$ & $\begin{array}{l}\text { Bersumber dari kehidupan yang religius, } \\
\text { adat yang kukuh, dan budaya Islam yang } \\
\text { kuat. } \\
\text { Telah membentuk sikap pantang } \\
\text { menyerah dan semangat nasionalisme. } \\
\text { Perlu dilestarikan dan dikembangkan } \\
\text { bersamaan dengan pengembangan } \\
\text { pendi-dikan. } \\
\text { Memerlukan adanya jaminan kepastian } \\
\text { hukum dalam melaksanakan segala } \\
\text { urusan. }\end{array}$ \\
\hline 5 & $\begin{array}{lr}\begin{array}{l}\text { Peraturan } \\
\text { Provinsi }\end{array} & \begin{array}{r}\text { Daerah } \\
\text { Gorontalo }\end{array}\end{array}$ & $\begin{array}{l}\text { Mengakui tata nilai dan norma hukum } \\
\text { yang berwawasan keislaman. }\end{array}$ \\
\hline
\end{tabular}




\begin{tabular}{|c|l|l|}
\hline & $\begin{array}{l}\text { Nomor 10 Tahun 2003 } \\
\text { tentang Pencegahan } \\
\text { Maksiat }\end{array}$ & $\begin{array}{l}\text { Mengembangkan tradisi budaya } \\
\text { masyarakat agar menjadi salah satu } \\
\text { norma hukum yang harus ditaati } \\
\text { bersama. }\end{array}$ \\
\hline 6 & $\begin{array}{l}\text { Peraturan Daerah Kota } \\
\text { Tangerang Nomor } 8 \\
\text { Tahun 2005 tentang } \\
\text { Pelarangan Pelacuran. }\end{array}$ & $\begin{array}{l}\text { Berlandaskan dan bersumber dari tata } \\
\text { nilai dan budaya masyarakatnya. } \\
\text { Yang hendak mengancam tata nilai dan } \\
\text { budaya masyarakat di Kota Tangerang. }\end{array}$ \\
\hline
\end{tabular}

\section{Implementasi Living law dan 'Urf dalam Putusan Peradilan}

Teori living law dan 'urf juga menjadi sumber hukum bagi hakim dalam memutuskan sutau perkara di pengadilan. Berikut ini beberapa contoh dari putusan peradilan yang mendasarkan pada living law, yaitu:

Pertama, Putusan Kasasi Mahkamah Agung No. 1178 K/Pid/2013 dalam perkara "membuat surat palsu atau memalsukan surat", sebagaimana diatur dan diancam pidana dalam Pasal 263 ayat (1) KUHP. Teori living law digunakan hakim MA dalam mengoreksi besaran sanksi pidana yang dijatuhkan oleh Pengadilan Tinggi Semarang, yang semula satu tahun dan enam bulan ${ }^{55}$ menjadi tiga tahun. ${ }^{56}$ Dalam pertimbangannya, hakim MA menyatakan: "Dari beberapa uraian tersebut di atas putusan Majelis Hakim Banding tersebut sangat bertentangan dengan rasa keadilan bagi masyarakat karena Hakim Pengadilan Tinggi Semarang yang memeriksa perkara ini dalam menerapkan keadilan tidak begitu saja mengucapkan apa yang tertuang dalam Undang-undang, namun berlaku Subsumtie automaat atau Letter Knachter der Wet seperti era Montesquieu, tetapi Hakim diberi kebebasan menilai dan menentukan keadilan sesuai the living law, sebagaimana yang tertuang di dalam Pasal 28 Undangundang Pokok Kekuasaan Kehakiman No. 4 Tahun 2004, oleh karenanya Judex Facti lebih cenderung menjatuhkan pidana lebih ringan dari pada putusan Pengadilan Negeri Klaten dan menurut kami hal itu merupakan putusan yang sangat ringan dan tidak mencerminkan rasa keadilan bagi masyarakat". ${ }^{57}$

Kedua, Putusan Peninjauan Kembali dari Mahkamah Agung No. No. 707 PK/Pdt/2011 tanggal 3 Februari 2012 dalam perkara waris. Teori living law digunakan hakim MA untuk mengoreksi putusan ahli waris perempuan. Dalam pertimbangannya hakim menyatakan:

\footnotetext{
55 Putusan MA No. 1178 K/Pid/2013, 13.

${ }^{56}$ Ibid., 15.

${ }^{57}$ Ibid., 13.
} 
"hukum positif yang baik adalah hukum yang sesuai dengan living law yang mencerminkan nilai-nilai yang hidup dalam masyarakat". ${ }^{88}$ Juga, "menurut hukum adat waris di Bali, anak perempuan tidak berhak waris, hanya berhak menikmati selama masih di rumah asal; Bahwa anak perempuan berhak mewarisi kalau dia berstatus laki-laki/status rajek/kawin kaceburin". ${ }^{9}$ Juga: "terdapat cukup alasan untuk mengabulkan permohonan peninjauan kembali dari Para Pemohon Peninjauan Kembali". ${ }^{60}$

Ketiga, Putusan Pengadilan Negeri Kabanjahe No. 20/Pid.B/2014/PN.KBJ tanggal 14 Mei 2014, dalam perkara kekerasan dalam rumah tangga, sebagaimana diatur dalam Pasal 44 ayat (2) Undang-undang No. 23 Tahun 2004 tentang Penghapusan Kekerasan Dalam Rumah Tangga. Teori living law digunakan hakim untuk menentukan keabsahan suatu pernikahan. Dalam pertimbangannya hakim menyatakan: "dalam perkara ini tenyata mengenai rumah tangga antara terdakwa dan saksi korban yang dilakukan secara adat istiadat Karo tidaklah sesuai dengan UndangUndang Nomor 1 Tahun 1974, karena tidak dilakukan sesuai agama dan kepercayaan terdakwa maupun saksi korban, akan tetapi Majelis Hakim berpendapat bahwa pernikahan secara adat istiadat karo ini dapat dikualifikasikan ke dalam rumah tangga karena Hakim wajib menggali nilai-nilai yang tumbuh dan hidup di tengah-tengah masyarakat, yang mana telah menjadi suatu relita yang tidak terbantah jika pernikahan secara adat istiadat ini banyak dan lazim dilakukan oleh masyarakat Karo dan telah menjadi suatu hukum yang hidup (living law)". ${ }^{61}$

Keempat, Putusan Pengadilan Hubungan Industrial pada Pengadilan Negeri Semarang No. 23/G/2013/PHI.SMG tanggal 16 Oktober 2013 dalam perkara perselisihan hubungan industrial. Teori living law digunakan hakim sebagai landasan berlakunya "peraturan lisan" yang berlaku di PT. Sarimadu Jayanusa Kendal. Dalam pertimbangannya hakim menyatakan: "meskipun peraturan di PT. Sarimadu Jayanusa tidak dibuat secara tertulis, majelis hakim berpendapat peraturan-peraturan tersebut, sebagai peraturan perusahaan, karena berlaku sebagai hukum yang hidup atau the living

58 Putusan PK-MA No. 707 PK/Pdt/2011 tanggal 3 Februari 2012, 15.

${ }^{59}$ Ibid., 15.

${ }^{60}$ Ibid., 16.

${ }^{61}$ Putusan PN Kabanjahe No. 20/Pid.B/2014/PN.Kbj tanggal 14 Mei 2014, 14. 
law, yang ditaati oleh karyawan yang ada di tempat tersebut". "Dalam melakukan PHK haruslah mempunyai landasan atau pijakan hukum". ${ }^{3}$

Dari beberapa contoh putusan tersebut maka bisa disajikan tabel sebagai berikut:

\begin{tabular}{|c|l|l|}
\hline No & Putusan Peradilan & $\begin{array}{l}\text { Bersumber dari Living } \\
\text { Law }\end{array}$ \\
\hline 1 & $\begin{array}{l}\text { Putusan Kasasi Mahkamah Agung No. } \\
1178 \text { K/Pid/2013 dalam perkara } \\
\text { "membuat surat palsu atau memalsukan } \\
\text { surat", sebagaimana diatur dan diancam } \\
\text { pidana dalam Pasal 263 ayat (1) KUHP. } \\
\text { pidana yang dijatuhkan } \\
\text { oleh Pengadilan Tinggi } \\
\text { Semarang, yang semula } \\
\text { satu tahun dan enam } \\
\text { bulan menjadi tiga } \\
\text { tahun. }\end{array}$ \\
\hline 2 & $\begin{array}{l}\text { Putusan Peninjauan Kembali dari } \\
\text { Mahkamah Agung No. No. 707 } \\
\text { PK/Pdt/2011 tanggal 3 Februari 2012 } \\
\text { dalam perkara waris. }\end{array}$ & $\begin{array}{l}\text { Karis perempuan. } \\
\text { wutusan Pengadilan Negeri Kabanjahe No. } \\
\text { 20/Pid.B/2014/PN.KBJ tanggal 14 Mei } \\
\text { 2014, dalam perkara kekerasan dalam } \\
\text { rumah tangga }\end{array}$ \\
\hline 4 & $\begin{array}{l}\text { Putusan Pengadilan Hubungan Industrial } \\
\text { pada Pengadilan Negeri Semarang No. } \\
\text { 23/G/2013/PHI. SMG tanggal 16 } \\
\text { Oktober 2013 dalam perkara perselisihan } \\
\text { hubungan industrial. }\end{array}$ & $\begin{array}{l}\text { Landasan bernikahan. } \\
\text { "peratu-ran lisan" yang } \\
\text { berlaku di PT. } \\
\text { Sarimadu Jayanusa } \\
\text { Kendal. }\end{array}$ \\
\hline
\end{tabular}

Selanjutnya akan dipaparkan beberapa contoh dari putusan peradilan yang mendasarkan pada 'urf, yaitu:

Pertama, Putusan Pengadilan Agama Bangko No 011/Pdt.G/2012/PA.Bko. tanggal 5 Maret 2012 dalam perkara cerai talak. Teori urf digunakan hakim sebagai landasan untuk menentukan besaran uang iddah, sebagaimana pertimbangan hakim: "Menimbang, bahwa berdasarkan Pasal 149 huruf b Kompilasi Hukum Islam, majelis hakim perlu menetapkan besaran uang 'iddah tersebut sesuai dengan kemampuan Tergugat rekonvensi dan kelayakan berdasarkan "urf dan kebiasaan". ${ }^{64}$ Besaran uang 'iddah tersebut adalah: (1) Rp

62 Putusan PHI pada PN Semarang No. 23/G/2013/PHI.Smg tanggal 16 Oktober 2013, 8 .

${ }^{63}$ Ibid., 9.

${ }^{64}$ Putusan PA Bangko No 011/Pdt.G/2012/PA.Bko. tanggal 5 Maret 2012, 18. 
2.400.000,- (dua juta empat ratus ribu rupiah) untuk nafkah mâdiyah selama 4 bulan; (2) Rp 1.800.000,- (satu juta delapan ratus ribu rupiah) untuk nafkah iddah selama 3 bulan sebesar; dan Rp 700.000,- (tujuh ratus ribu rupiah) untuk mut' $a b^{65}$

Kedua, Putusan Pengadilan Agama Takalar No. 127/Pdt. G/2012/PA Tkl tanggal 19 Februari 2013 dalam perkara cerai gugat. Teori urf digunakan hakim sebagai landasan untuk menentukan 'urf terhadap kebiasaan yang ada dalam masyarakat, yang berupa kawin lari. Hakim menyatakan bahwa: "memandang urgen pula untuk menegaskan dalam disenting ini bahwa perbuatan kawin lari, sebagaimana telah dilakukan oleh Penggugat dan Tergugat, yang juga telah dikenal dalam praktik hukum di masyarakat bersuku Makassar, khususnya di wilayah Kabupaten Takalar, bukanlah suatu kebiasaan yang baik, sehingga tidak tergolong 'urf sahîh, melainkan 'urf fâsid, yang tidak dapat dijadikan sebagai alat ber-istidlâl atau landasan normatif dalam pengambilan keputusan hukum". ${ }^{66}$

Ketiga, Putusan Pengadilan Agama Binjai No. 204/Pdt.G/2014/PA.Bji. tanggal 21 Januari 2015 dalam perkara harta bersama. Teori 'urf digunakan hakim sebagai landasan hukum tentang adanya harta bersama dalam suatu perkawinan. Hakim menyatakan dalam pertimbangannya, bahwa: "secara sosiologis atau 'urf di kalangan masyarakat Indonesia telah mempraktikkan adanya harta bersama dalam perkawinan, suami dan istri merupakan korporasi dua badan (shirkah abdân) dalam mengupayakan harta bersama tersebut. Hal itu disebabkan keuangan keluarga bukan cuma suami atau istri saja, akan tetapi baik suami maupun istri punya andil dalam mendatangkan sumber keuangan keluarga, baik dalam suatu jenis pekerjaan yang sama atau tidak, sekalipun seorang istri hanya berperan sebagai ibu rumah tangga". ${ }^{67}$

Keempat, Putusan Pengadilan Agama Stabat No. 434/Pdt.G/2015/PA.Stb. tanggal 9 Juli 2015 dalam perkara perkara permohonan cerai talak. Teori 'urf digunakan hakim sebagai landasan untuk menentukan apakah telah terjadi hubungan suami istri. Hakim menyatakan dalam pertimbangannya, bahwa: "Pemohon Dalam Konvensi mendalilkan telah melakukan hubungan suami istri dengan Termohon Dalam Konvensi dan telah pula dikaruniai anak dari

\footnotetext{
${ }^{65}$ Ibid., 20.

${ }^{66}$ Putusan PA Takalar No. 127/Pdt. G/2012/PA Tkl tanggal 19 Februari 2013, 21.

${ }^{67}$ Putusan PA Binjai No. 204/Pdt.G/2014/PA.Bji. tanggal 21 Januari 2015, 18.
} 
perkawinannya dengan Termohon Dalam Konvensi, sedangkan Termohon Dalam Konvensi tidak membantah dalil tersebut, maka Majelis Hakim berpendapat berdasarkan hukum kebiasaan ('urf) anak yang lahir dalam perkawinan karena adanya hubungan suami istri, maka Majelis Hakim berpendapat Pemohon Dalam Konvensi dan Termohon Dalam Konvensi telah melakukan hubungan suami istri (ba'd al-dukhûl)". 68

\begin{tabular}{|c|l|l|}
\hline No & Putusan Peradilan & \multicolumn{2}{|l|}{ Bersumber dari Urf } \\
\hline 1 & $\begin{array}{l}\text { Putusan Pengadilan Agama Bangko No } \\
011 / \text { Pdt.G/2012/PA.Bko. tanggal 5 } \\
\text { Maret 2012 dalam perkara cerai talak. }\end{array}$ & $\begin{array}{l}\text { Landasan untuk } \\
\text { menentukan besaran } \\
\text { uang iddah. }\end{array}$ \\
\hline 2 & $\begin{array}{l}\text { Putusan Pengadilan Agama Takalar No. } \\
\text { 127/Pdt. G/2012/PA Tkl tanggal 19 } \\
\text { Februari 2013 dalam perkara cerai gugat. }\end{array}$ & $\begin{array}{l}\text { Landasan menentukan } \\
\text { urf terhadap kebiasaan } \\
\text { yang ada dalam } \\
\text { masyarakat, yang berupa } \\
\text { kawin lari. }\end{array}$ \\
\hline 3 & $\begin{array}{l}\text { Putusan Pengadilan Agama Binjai No. } \\
\text { 204/Pdt.G/2014/PA.Bji. tanggal 21 } \\
\text { Januari 2015 dalam perkara harta } \\
\text { bersama. }\end{array}$ & $\begin{array}{l}\text { Landasan hum } \\
\text { tentang adanya harta } \\
\text { bersama dalam suatu } \\
\text { perkawinan. }\end{array}$ \\
\hline 4 & $\begin{array}{l}\text { Putusan Pengadilan Agama Stabat No. Nan } \\
\text { 434/Pdt.G/2015/PA.Stb. tanggal 9 Juli } \\
\text { 2015 dalam perkara perkara permohonan } \\
\text { cerai talak. }\end{array}$ & $\begin{array}{l}\text { Landasan menentukan } \\
\text { apakah telah terjadi } \\
\text { hubungan suami istri. }\end{array}$ \\
\hline
\end{tabular}

\section{Penutup}

Living law merupakan hukum yang mendominasi kehidupan itu sendiri meskipun belum dibahas di dalam proposisi hukum, sedangkan 'urf merupakan sesuatu yang biasa dilakukan dan telah umum dalam sekelompok orang (jumbûr) berupa perkataan dan perbuatan, dan secara konsisten diulang sampai mempengaruhi mereka dan oleh karena itu mereka menerimanya. Di sinilah titik temu antara living law dan urf, yaitu hukum adalah sesuatu yang ada dan sudah mentradisi meskipun itu bukan merupakan hukum.

Keberadaan living law dan "urf telah diakui dalam sistem hukum nasional, yaitu dengan adanya (1) kewajiban hakim menggali, mengikuti, dan memahami nilai-nilai hukum dan rasa keadilan yang hidup dalam masyarakat; (2) pengakuan kebiasaan sebagai sumber

68 Putusan PA Stabat No. 434/Pdt.G/2015/PA.Stb. tanggal 9 Juli 2015, 15. 
hukum formal; dan (3) Pasal 32 ayat (1) dari Undang-undang Dasar Negara Republik Indoneisa Tahun 1945.

Teori living law dan 'urf telah diimplementasikan dalam sistem hukum nasional. Sebagai contoh bisa dilihat dalam konsideran beberapa undang-undang, antara lain (1) Undang-undang Nomor 23 Tahun 2014 tentang Pemerintahan Daerah, (2) Undang-undang Nomor 21 Tahun 2008 tentang Perbankan Syariah, (3) UndangUndang Nomor 23 Tahun 2011 tentang Pengelolaan Zakat, (4) Undang-undang Nomor 44 Tahun 1999 tentang Penyelenggaraan Keistimewaan Propinsi Daerah Istimewa Aceh, (5) Peraturan Daerah Provinsi Gorontalo Nomor 10 Tahun 2003 tentang Pencegahan Maksiat, dan (6) Peraturan Daerah Kota Tangerang Nomor 8 Tahun 2005 tentang Pelarangan Pelacuran.

Teori living law telah dijadikan sumber hukum oleh hakim dalam memutuskan suatu perkara, semisal dalam memutuskan: (1) besaran sanksi pidana, (2) ahli waris perempuan, (3) keabsahan suatu pernikahan, dan (4) berlakunya "peraturan lisan". Di sisi lain teori "urf juga telah dijadikan sumber hukum oleh hakim dalam memutuskan suatu perkara, semisal dalam memutuskan: (1) besaran uang iddah, (2) validasi kawin lari, (3) harta bersama dalam perkawinan, dan (4) menentukan apakah telah terjadi hubungan suami istri ( $b a^{\prime} d$ al-dukbûl).

\section{Daftar Rujukan}

Ali, Achmad. Menguak Tabir Hukum. Jakarta: Gunung Agung, 2002.

Antonov, Mikhail. "Eugen Ehrlich: State Law and Law Enforcement in Societal Systems", Law WP-BRP, Vol. 33, 2014.

Christianto, Hwian. "Penafsiran Hukum Progresif dalam Perkara Pidana”, Mimbar Hukum, Vol. 23, No. 3, Oktober 2011.

Elias, Rodrigo Fernandes. "Penemuan Hukum dalam Proses Peradilan Pidana di Indonesia", Jurnal LPPM Bidang EkoSosBudKum, Vol. 1 No. 1, 2014.

Ghani, Hafiz Abdul. "'Urf -o-Ādah (Custom and Usage) as a Source of Islamic Law", American International Journal of Contemporary Research, Vol. 1, No. 2, September 2011.

----. "Conditions of a Valid Custom in Islamic and Common Laws", International Journal of Business and Social Science, Vol. 3 No. 4, Special Issue-February 2012.

Hay, Marhaenis Abdul. Dasar-dasar Ilmu Hukum. Jakarta: Pradnya Paramita, 1986. 
Hertogh, Marc (et.al). Living Law: Reconsidering Eugen Ehrlich. Oxford: Hart Publishing Ltd, 2009.

Husna TR, Cut Asmaul. "Penemuan dan Pembentukan Hukum "The Living Law" Melalui Putusan Hakim”, Mizan, Vol. 2 No. 3, Februari 2012.

Ismi, Hayatul. "Pengakuan dan Perlindungan Hukum Hak Masyarakat Adat atas Tanah Ulayat dalam Upaya Pembaharuan Hukum Nasional", Jurnal Imu Hukum, Vol. 3 No. 1, 2012.

Kansil, C.S.T. Pengantar Ilmu Hukum dan Tata Hukum Indonesia. Jakarta: Balai Pustaka, 1989.

Khallâf, 'Abd al-Wahhâb. Tlm Uș̂ul al-Fiqh. Mesir: Maktabah alDakwah-Syababul Azhar, 2009.

Kuswardani. "Pengembangan Metodologi Berbasis Sociology Jurisprudence", Prosiding Seminar Nasional Pengembangan Epistemologi Ilmu Hukum, Surakarta, UMS, April-2015.

Maula, Bani Syarif. "Realitas Hukum Islam dalam Konfigurasi Sosial dan Politik di Indonesia: Perspektif Sosiologi Hukum Tentang Perkembangan Hukum Islam di Indonesia", Hermeneia: Jurnal Kajian Islam Interdisipliner, Vol. 2 No. 2, Juli-Desember 2003.

Mubarok, Nafi'. "Penemuan Hukum sebagai Pertimbangan Sosiologis Hakim Agama dalam Menerapkan Hukum”, al-Qânûn, Vol. 17, No. 2, Desember 2014.

Nelken, David. "Eugen Ehrlich, Living Law, and Plural Legalities", Theoretical Inquiries in Law, Vol. 9.2, 2008.

Nurjaya, I Nyoman. "Memahami Kedudukan dan Kapasitas Hukum Adat dalam Politik Pembangunan Hukum Nasional", Perspektif, Vol. 16, No. 4, September-2011.

Putusan MA No. 1178 K/Pid/2013.

Putusan PA Bangko No 011/Pdt.G/2012/PA.Bko. tanggal 5 Maret 2012.

Putusan PA Binjai No. 204/Pdt.G/2014/PA.Bji. tanggal 21 Januari 2015.

Putusan PA Stabat No. 434/Pdt.G/2015/PA.Stb. tanggal 9 Juli 2015. Putusan PA Takalar No. 127/Pdt. G/2012/PA Tkl tanggal 19 Februari 2013.

Putusan PHI pada PN Semarang No. 23/G/2013/PHI.Smg tanggal 16 Oktober 2013.

Putusan PK-MA No. 707 PK/Pdt/2011 tanggal 3 Februari 2012. 
Putusan PN Kabanjahe No. 20/Pid.B/2014/PN.Kbj tanggal 14 Mei 2014.

Rasjidi, Lili. dan Rasjidi, Ira Tania. Dasar-dasar Filsafat Hukum dan Teori Hukum. Bandung: Citra Aditya Bakti, 2004.

Rosidin, Dedeng. Diktat Ushul Fiqih. Bandung: FPBS-Universitas Pendidikan Bandung, 2010.

Salman, R. Otje. Beberapa Aspek Sosiologi Hukum. Bandung: Alumni, 1993.

Shabana, Ayman. Custom in Islamic Law and Legal Theory: The Development of the Concepts of 'Urf and 'Adab in the Islamic Legal Tradition. New York: Palgrave Macmillan, 2010.

Sirajuddin M. "Eksistensi 'Urf sebagai Sumber Pelembagaan Hukum Nasional", Madania, Vol. 19, No. 1, Juni 2015.

Sudikno. Mengenal Hukum. Yogyakarta: Liberty, 1999.

Suherman, Ade Maman. Pengantar Perbandingan Sistem Hukum, Civil Law, Common Law, Hukum Islam. Jakarta: Raja Grafindo Persada, 2006.

Tanya, Bernard L. dkk., Teori Hukum: Strategi Tertib Manusia Lintas Ruang dan Generasi. Surabaya: CV. Kita, 2007.

Yusra, Dhoni. "Politik Hukum Hakim dibalik Penemuan Hukum (Rechtsvinding) dan Penciptaan Hukum (Rechtsschepping) pada Era Reformasi dan Transformasi", Lex Jurnalica, Vol. 10 No. 2, Agustus 2013.

Zuhaylî (al), Wahbah. al-Wajî̀ fî Ușûl al-Fiqh. Damaskus: Dâr al-Fikr, 1999. 